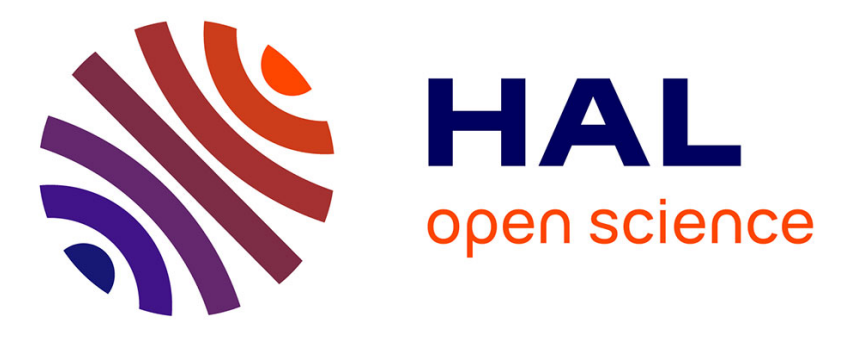

\title{
Elevation changes inferred from TanDEM-X data over the Mont-Blanc area: Impact of the X-band interferometric bias
}

\author{
Amaury Dehecq, Romain Millan, Etienne Berthier, Noel Gourmelen, \\ Emmanuel Trouvé, Vincent Vionnet
}

\section{To cite this version:}

Amaury Dehecq, Romain Millan, Etienne Berthier, Noel Gourmelen, Emmanuel Trouvé, et al.. Elevation changes inferred from TanDEM-X data over the Mont-Blanc area: Impact of the X-band interferometric bias. IEEE Journal of Selected Topics in Applied Earth Observations and Remote Sensing, 2016, 99, pp.1-13. 10.1109/JSTARS.2016.2581482 . hal-01354172

\author{
HAL Id: hal-01354172 \\ https://hal.science/hal-01354172
}

Submitted on 17 Aug 2016

HAL is a multi-disciplinary open access archive for the deposit and dissemination of scientific research documents, whether they are published or not. The documents may come from teaching and research institutions in France or abroad, or from public or private research centers.
L'archive ouverte pluridisciplinaire HAL, est destinée au dépôt et à la diffusion de documents scientifiques de niveau recherche, publiés ou non, émanant des établissements d'enseignement et de recherche français ou étrangers, des laboratoires publics ou privés.

\section{(ㅇ)(1) $\$$}

Distributed under a Creative Commons Attribution - NonCommercial - NoDerivatives| 4.0 


\title{
Elevation changes inferred from TanDEM-X data over the Mont-Blanc area: Impact of the $\mathrm{X}$-band interferometric bias
}

\author{
Amaury Dehecq, Romain Millan, Etienne Berthier, Noel Gourmelen, Emmanuel Trouvé, Senior
}

Member, IEEE, Vincent Vionnet

\begin{abstract}
The TanDEM-X mission allows generation of Digital Elevation Models (DEM) with high potential for glacier monitoring, but the radar penetration into snow and ice remains a main source of uncertainty. In this study, we generate 5 new DEMs of the Mont-Blanc area from TanDEM-X interferometric pairs acquired in 2012/2013. We conducted a multi-temporal analysis of the DEMs in comparison with two high-resolution DEMs obtained from Pléiades stereo satellite images in 2012 and 2013. A vertical precision of $1-3 \mathrm{~m}$ of the radar DEMs is estimated over ice and snow free areas and slopes less than $40^{\circ}$. DEM-derived elevation changes are compared with outputs of the snowpack model Crocus and snow accumulation measurements. The results show that at altitudes below $\sim 2500 \mathrm{~m}$ a.s.l., the radar penetration is negligible in our study area. The DEM-derived elevation changes agree, within uncertainty, with the modelled and field snow height. At higher altitudes, the comparison between the radar and optical DEMs acquired only a few weeks apart allows estimating the interferometric bias of the X-band DEM in the dry snowpack. At $4000 \mathrm{~m}$ a.s.l,
\end{abstract}

A. Dehecq, R. Millan, E. Trouvé are with LISTIC, Université Savoie Mont Blanc Annecy-Le-Vieux, France.

E. Berthier is with LEGOS, Université de Toulouse, CNES, CNRS, IRD, UPS, France.

N. Gourmelen is with School of Geosciences, University of Edinburgh, Edinburgh, UK.

V. Vionnet is with Météo-France/CNRS, CNRM - GAME UMR 3589, Centre d'Etudes de la Neige, Grenoble, France it reaches $4 \mathrm{~m}$ on average in October and February. A geodetic glacier mass balance calculated using the October radar DEM would be biased. For the least favourable case, the highly elevated Bossons glacier, the bias would correspond to $1.66 \mathrm{~m}$ w.e. This error is too large to derive significant annual mass balances, but similar to elevation or seasonality uncertainties if integrated over a 10 years period.

Keywords-Synthetic Aperture Radar Interferometry (InSAR), TanDEM-X, Multi-temporal DEM, DEM differencing, Radar penetration, Glaciers, Snow, Geodetic mass balance

\section{INTRODUCTION}

The TanDEM-X (TDX) mission launched on June 21, 2010 is an extension of the TerraSAR-X mission permitting the construction of high resolution Digital Elevation Models (DEM) [1]. The two satellites operating in Xband $(9.65 \mathrm{GHz})$ are flying in close formation. It enables acquisitions of two Synthetic Aperture Radar (SAR) images within a single pass, which avoids temporal decorrelation and atmospheric perturbations in SAR interferometry (InSAR). The final product delivered by the DLR (German Aerospace Center) should be unprecedented at a global scale, with an expected accuracy of $2 \mathrm{~m}$ for slope lower than $20 \%$ and $4 \mathrm{~m}$ above. This new library of digital elevation models open the doors to multiple applications in geosciences and particularly 
in glaciology with the ability to derive glacier volume changes at high resolution.

However, high mountainous terrain and the acquisition geometry of SAR images make derivation of digital elevation models from InSAR difficult to implement. In these regions, the TanDEM-X mission plan to combine acquisitions with different baselines and with opposite looking directions to avoid unwrapping errors and gaps due to shadow/layover [1]. The phase unwrapping strategy is to use a dualbaseline approach based on the use of the combined information from a first year of acquisition with a height of ambiguity (HoA) of 40-55 $\mathrm{m}$ and a second year with a smaller HoA of about $35 \mathrm{~m}$ [2, 3], resulting in a significantly improved final DEM. However, the combination of multiple scenes acquired at different dates is not suitable for glaciological applications where rapid, seasonal and annual changes can occur. Several studies have shown that the use of single TanDEM-X pairs allows observing glacier elevation changes at annual scales, for ice sheets and ice caps $[4,5,6,7]$ or mountain glaciers [8]. But to our knowledge, no study has yet assessed the potential and limits of using a series of TDX DEMs for the monitoring of mountain glacier elevation changes at seasonal scales.

Another major issue when using SAR data for glaciological applications is the penetration of the radar signal into snow and ice. A one-way X-band (10.3 GHz) penetration depth of $8.1 \mathrm{~m}$ has been measured on the Antarctic plateau [9] and a Ku-band (13.6 GHz) penetration depth of $5.7 \pm 1.2 \mathrm{~m}$ has been measured in summer snow in Antarctica [10]. This penetration causes the displacement of the interferometric phase center below the surface, resulting in a negative bias between the elevation measured by InSAR and the actual surface, hereafter referred to as the interferometric bias [11]. This interferometric bias has been estimated for the Cband $(5.3 \mathrm{GHz})$ to be $9 \pm 2 \mathrm{~m}$ in cold polar firn and
$4 \pm 2 \mathrm{~m}$ on temperate ice [12] or $13 \mathrm{~m}$ on a peripheral ice cap in Greenland [13]. Groh et al. [14] estimated an $\mathrm{X}$-band interferometric bias of about $5 \mathrm{~m}$ in dry snow in Antarctica.

Up to date, very few estimates exist for mountain glaciers and radar penetration remains one of the main sources of uncertainty when using radar DEMs to derive a geodetic glacier mass balance $[15,16,17]$. In order to estimate the interferometric bias of the Shuttle Radar Topography Mission (SRTM) C-band DEM over Himalayan glaciers, Gardelle et al. [15] computed the difference between the C-band and X-band SRTM DEMs where available, making the strong assumption of a negligible X-band penetration. They estimated an average $\mathrm{C}$-band interferometric bias in the range of 1.7-3.4 m among all sites. By estimating ICESat (laser) elevation trends over the period 2003-2009 with reference to the SRTM C-band DEM, Kääb et al. [16] calculated an average interferometric bias of up to $10 \mathrm{~m}$ for the same regions in the Pamir-Karakoram-Himalaya. This large disagreement likely contradict the hypothesis of a negligible $\mathrm{X}$-band penetration in mountain glaciers, and shows that more information is needed to constrain or reduce the impact of radar penetration on estimates of glacier geodetic mass balance. Moreover, due to the sparse coverage of ICESat, this approach does not allow to fully map the interferometric bias and to relate it, for example, to altitude or glacier surface state.

In this study, we process TanDEM-X SAR scenes, acquired between May 2012 and November 2013 to derive 5 new DEMs in the Mont-Blanc area. They have been obtained by means of SAR interferometry (InSAR) using a high-resolution DEM obtained from Pléiades stereo satellite images as a reference for the phase unwrapping. We assess the uncertainties by comparing the elevation differences between the multi-temporal TDX DEMs with the Pléiades DEM over ice, snow and vegetation free areas. At high altitude, the observed 
elevation changes are validated against measured and modelled snow height. We then estimate the interferometric bias in snow and firn by comparing the optical and radar DEMs obtained at close dates and discuss the impact of this bias on geodetic glacier mass balance. At last, the impact of the reference DEM used to produce the TDX DEMs is discussed.

\section{DATA}

\section{A. Study area}

The Mont-Blanc massif contains some of the largest glaciers in the Alps including the Mer de Glace (30 $\left.\mathrm{km}^{2}\right)$ and the Argentière Glacier $\left(12 \mathrm{~km}^{2}\right.$, Figure 1). It is characterised by its high and steep topography. In a roughly $35 \mathrm{~km}$ long and $13 \mathrm{~km}$ wide area, altitude varies from $1000 \mathrm{~m}$ a.s.l. in the Chamonix valley up to $4810 \mathrm{~m}$ a.s.l at the top of the Mont-Blanc. This region has been monitored for over 40 years by in-situ measurements and satellite imagery $[18,19,20,21]$. Berthier and Vincent observed by mean of DEM differencing that the thinning rate of the Mer de Glace increased from $1 \mathrm{~m} / \mathrm{yr}$ to $4 \mathrm{~m} / \mathrm{yr}$ between the periods 1979-1994 and 20002008 [20], affecting local water resources and tourism activities which represent important economical sources for the region.

\section{B. Spaceborne data}

Between May 2012 and November 2013, five pairs of TDX images were acquired over this region, with both ascending and descending configurations and different baselines (Table I). We used the Coregistered Single look Slant range Complex (CoSSC) images that are already focused and co-registered. For the accuracy assessment and the temporal analysis, we used two $4 \mathrm{~m}$ resolution DEMs obtained from stereo images acquired by the Pléiades satellites in August 2012 and September 2013 [22] (Table II). The vertical accuracy of the Pléiades DEMs was checked against field measurements and found to
TABLE I. PAIRS OF TANDEM-X IMAGES USED IN THIS STUDY (BPERP : PERPENDICULAR BASELINE, HoA : HEIGHT OF AMBiguity).

\begin{tabular}{cccccc}
\hline Date & Time & Orbit & Bperp $(\mathrm{m})$ & HoA $(\mathrm{m})$ & Incidence \\
\hline $2012 / 05 / 13$ & $18: 25$ & Ascending & 176.3 & 30.3 & $44^{\circ}$ \\
$2012 / 05 / 24$ & $18: 25$ & Ascending & 170.8 & 31.0 & $44^{\circ}$ \\
$2013 / 02 / 01$ & $18: 25$ & Ascending & 122.8 & 58.8 & $44^{\circ}$ \\
$2013 / 10 / 21$ & $06: 45$ & Descending & 80.4 & 63.7 & $37^{\circ}$ \\
$2013 / 11 / 12$ & $06: 45$ & Descending & 95.0 & 62.3 & $37^{\circ}$ \\
\hline
\end{tabular}

TABLE II. REFERENCE DEMS USED IN THIS STUDY

\begin{tabular}{ccc}
\hline Data/Mission & Date & Posting $(\mathrm{m})$ \\
\hline Pléiades & $2012 / 08 / 19$ & 4 \\
Pléiades & $2013 / 09 / 20$ & 4 \\
SRTM-C & Feb. 2000 & 30 \\
\hline
\end{tabular}

be $1 \mathrm{~m}$ [22]. The $30 \mathrm{~m}$ resolution SRTM C-band DEM [23] version 3 was used to analyse the impact of the reference DEM on the final result. Voids in the original SRTM DEM were eliminated using ASTER GDEM2 and other secondary sources (see www.dx.doi.org/10.5067/MEaSUREs/SRTM/SRTMGL1.003). Unfortunately, the SRTM X-band DEM was not available over our study area for comparison. A Landsat 8 scene (LC81950282013188LGN00) acquired in July 82013 was used to mask out the vegetation for the alignment of the DEMs. Glacier outlines were manually identified on a SPOT5 $2.5 \mathrm{~m}$ ortho-image acquired on August 23, 2003.

\section{Snowpack data}

In order to validate our interpretation of the elevation changes observed from the satellite data, we used snow pit measurements where available, and outputs of a snowpack model driven by meteorological re-analysis.

The snow pit measurements consist of 18 accumulation measurements carried out on the Mer de Glace, Argentière and Tour Noir glaciers in May 2012 between 2740 and $3570 \mathrm{~m}$ a.s.1. in the frame of the GLACIOCLIM observatory [24, http://www-lgge.ujfgrenoble.fr/ServiceObs/]. 




$6.9^{\circ} \mathrm{E}$

$7^{\circ} \mathrm{E}$

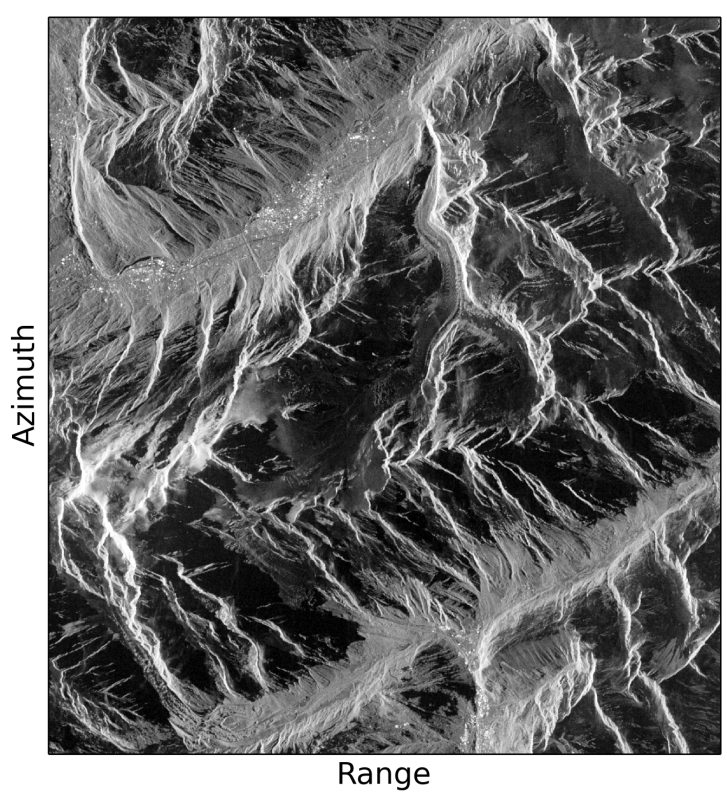

Fig. 1. Left : Shaded relief of the Pléiades 2012 DEM over the Mont-Blanc massif. Glaciers are displayed in blue, with the Mer de Glace and Bossons glaciers outlined in red, and the Mont-Blanc summit marked with a yellow triangle. Right : Amplitude of the TDX 2012/05/13 ascending image in SAR geometry.

Unfortunately, these field measurements are not available at all altitudes and do not provide information on snowpack properties such as the liquid water content, which is a crucial variable affecting radar penetration $[25,13,26]$. Thus, we completed our analysis with outputs from the detailed snowpack model Crocus [27, 28]. Crocus is a one-dimensional multilayer physical snow scheme that simulates the evolution of the snowpack as a function of energy and mass transfer between the atmosphere and the snowpack. The model is fully coupled to the ISBA land surface model [29], allowing a thermodynamic coupling to the soil component of the land surface model. For each layer of the snowpack, Crocus simulates the evolution of the thickness, density, temperature, liquid water content and age. Additional variables describe the evolution of snow grains using metamorphism laws [27]. Crocus represents the main physical processes involved in snowpack evolution and in particular liquid water flow and refreezing through the snowpack. Liquid water in the snowpack can results from melting or rainfalls at the top of the snowpack. For the purpose of this study, we used the output of the model driven by the SAFRAN re-analysis [30] over the Mont-Blanc massif. SAFRAN and Crocus are operationally used at Météo France for avalanche hazard forecasting [31, 32]. In this configuration, the snow properties are simulated at 15 minutes time steps for a maximum of 50 snow layers. The model is run at $300 \mathrm{~m}$ elevation steps (from 1200 to $3600 \mathrm{~m}$ a.s.l) for 8 terrain aspects (N, NE, E, SE, S, SW, W, NW) and 2 slope conditions $\left(20^{\circ}, 40^{\circ}\right)$ plus the plane, i.e 17 surfaces in total per elevation step. It does not take into account the redistribution of snow from wind/avalanches and projected shadows. Model outputs are available at 6 hour intervals. 


\section{Methodology}

\section{A. DEM processing}

The TDX pairs were processed using conventional SAR interferometry with the GAMMA software (e.g [33]). However, in this mountainous region, steep slopes, shadows and layover can induce phase discontinuities between different regions of the interferogram. In order to minimize errors when resolving the phase ambiguities (see section V-B), a reference DEM is introduced during the unwrapping stage (as also suggested by $[5,8])$. Because of its temporal proximity and high resolution, the Pléiades 2012 DEM was used as a reference for the processing. The impact of the reference DEM on the final result is further discussed in section V-B. The processing steps, represented on Figure 2, are as follows :

- an interferogram is computed from the SAR images and multi-looked $5 \times 5$ in order to improve the interferometric phase and coherence estimations.

- a look-up table is deduced from the orbits and the reference DEM in order to convert coordinates between radar and ground geometries.

- using the look-up table and the reference DEM (Pléiades 2012), a simulated amplitude image and interferogram are produced and coregistered to the TDX scene using offset-tracking [34]. It allows a refining of the look-up table.

- a differential single-pass interferogram is computed as the difference between the TDX singlepass interferogram and the simulated interferogram.

- the differential single-pass interferogram is filtered using the adaptive interferogram filter "adf" [35] of the Gamma software to improve fringe visibility/remove noise. Points with a coherence below 0.3 are removed.

- the phase difference is unwrapped using a Minimum Cost Flow algorithm (MCF, [36]).
- the final DEM is produced by converting the unwrapped phase difference to height using orbital state vectors and reference elevation, adding the reference DEM elevation, and geocoding based on the look-up table.

\section{B. DEM alignment}

The produced DEMs must be correctly aligned, horizontally and vertically, in known stable areas (e.g. rocks, meadows), not covered by ice, snow or tall vegetation like forests. Glaciers contours were manually identified. In order to mask out the vegetation, which is penetrated by the radar signal, we calculated a Normalized Difference Vegetation Index (NDVI) from the Landsat bands 4 (B4) and 5 (B5) [37]:

$$
\mathrm{NDVI}=\frac{B 5-B 4}{B 5+B 4}
$$

This index is in the range $[-1,1]$ and characterizes the vegetation density. We filtered out all points where NDVI $>0.3$. All DEMs were aligned to the Pléiades 2012 DEM. The alignment was made in three steps.

1. The DEM was re-sampled to the Pléiades grid using bilinear interpolation.

2. A horizontal shift was calculated using the method proposed in [38], by fitting a sinusoidal relationship between elevation differences and terrain aspect.

3. A vertical shift with a linear dependence on location (tilt) was estimated for each DEM using a least square regression :

$$
d h(X, Y)=a_{0}+a_{1} X+a_{2} Y
$$

where dh are elevation differences in stable areas, $\mathrm{X}$ and $\mathrm{Y}$ the easting and northing and $a_{i}$ the parameters to be estimated. This shift is then subtracted at each pixel. For this step, which is more sensitive to outliers, all points with a slope higher than $40^{\circ}$ were excluded, as well as points higher than $1500 \mathrm{~m}$ a.s.l., i.e potentially snow covered areas. 


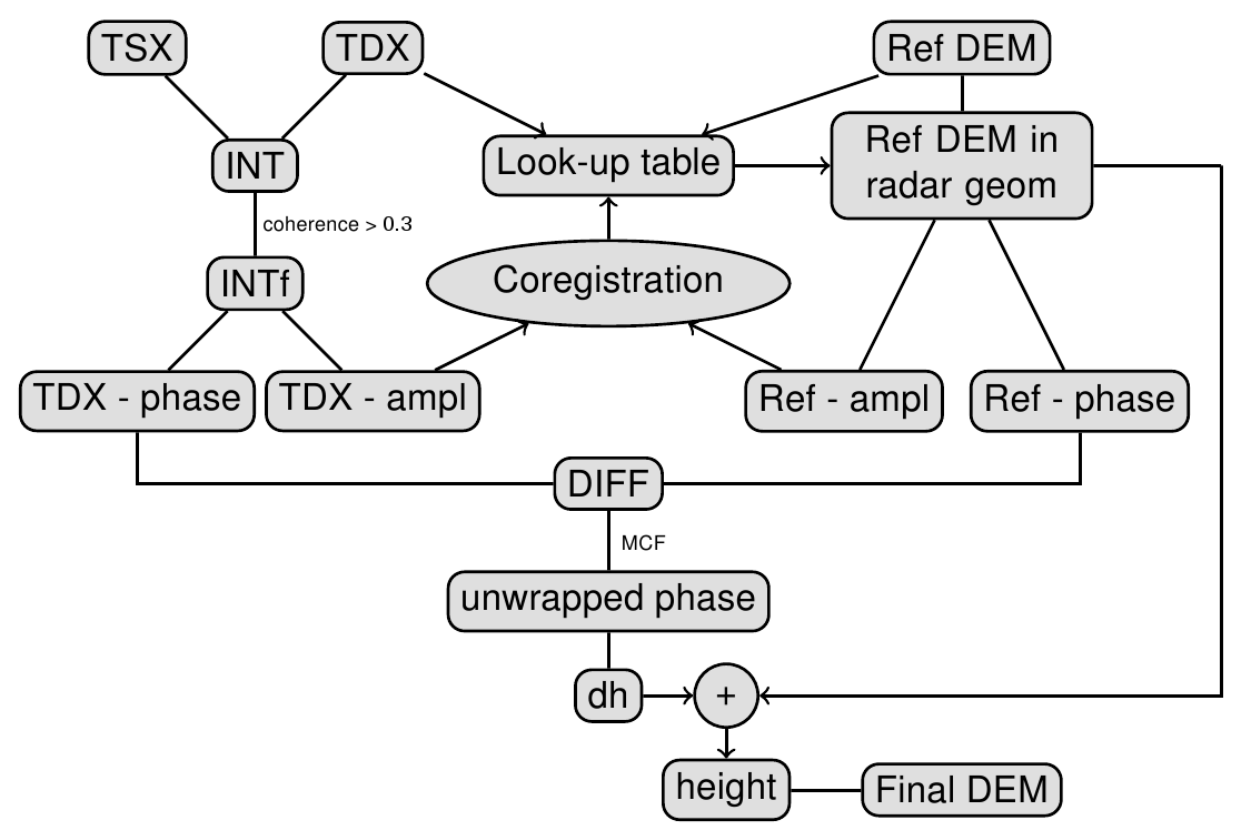

Fig. 2. Diagram of the processing scheme used for the TDX pairs in this study. TSX/TDX : TDX image pairs, INT(f) : (filtered) interferogram, ampl : amplitude, Ref DEM : Reference DEM, DIFF : differential single-pass interferogram, dh : elevation difference (m)

To test the accuracy of the horizontal alignment, the Pléiades 2012 DEM was shifted and a Gaussian noise with a $2 \mathrm{~m}$ standard deviation was added before attempting to align it with the original DEM. The correct shift was estimated with an accuracy better than $1 / 10$ of a pixel.

The threshold of $40^{\circ}$ was estimated by looking at the elevation differences between the two Pléiades DEMs off ice. These differences have a standard deviation in the range of a few meters for slopes below $40^{\circ}$ but the value increases rapidly to reach a few tens of meters on the steepest slopes, where even a small residual horizontal shift can lead to large elevation differences.

Ground Control Points (GCPs) were not used for the vertical alignment for several reasons. First, even in a well monitored area, the number of GCPs available would be much lower than what is provided by the Pléiades DEMs, and they should be evenly distributed on the study area in order to correctly estimate a potential tilt. Secondly, GCPs are generally placed on easily recognized features such as buildings or rocks. The elevation of such features is generally not very well estimated at a $4 \mathrm{~m}$ resolution and due to multiple rebounds of the radar signal.

\section{Uncertainty estimate}

Due to the large tails of the elevation change distributions, median and normalised median absolution deviation (NMAD) were used as statistical estimators for the uncertainty, rather than mean and standard deviation, which are more sensitive to outliers [39].

$$
\operatorname{NMAD}=1.4826 \operatorname{median}\left(\left|\Delta h_{j}-m_{\Delta h}\right|\right)
$$

where $\Delta h_{j}$ denotes the individual elevation differences and $m_{\Delta h}$ is the median of all $\Delta h_{j}$.

For all the analyses, points with slopes higher than $40^{\circ}$ were also excluded.

\section{Comparison with snowpack data}

We used the snowpack model outputs and snow pit measurements to validate and support the interpretation 
of the elevation changes derived from the satellite data. The model is useful to estimate the snow height at most altitudes, which is not allowed by the snow pit measurements available. But its main interest resides in its ability to simulate the evolution of the liquid water content with time and throughout the snow layers, information that can be used as an indicator of possible radar penetration. Unfortunately, the model outputs are not spatially distributed and cannot be directly compared with the elevation changes observed from the satellite data or the snow pit measurements. Instead, we used the model to determine a snow height interval at each altitude band, and when and where X-band radar penetration can be expected.

First, the height of snow aged less than a year was computed from the model output. The condition on the age is necessary for altitudes above $3000 \mathrm{~m}$, where snow accumulates from year to year in the model and the absolute snow height depends on the start of the simulation. Secondly, among all the slope and aspect model configurations, the minimum and maximum snow height are computed at each time step to yield a snow height interval. The maximum generally coincide with north-oriented $40^{\circ}$ slopes, whereas the minimum generally occurs for south-oriented $40^{\circ}$ slopes that receive most solar radiation. At last, to estimate the possibility of X-band radar penetration in snow for these two extreme cases, the depth of the first "wet" snow layer is retrieved from the snow layers properties. The snow is considered as "wet" when the volumetric liquid water content exceeds $1 \%$ as the X-band radar penetration can be considered negligible $(<10 \mathrm{~cm})$ in these conditions [26, Fig. 5]. The snow overlying this first wet layer is hereafter called "dry" snow and can potentially be penetrated by the X-band radar signal.

The model snow height intervals are then compared to the off-ice elevation changes between each available DEM and the Pléiades 2013/09/20 DEM, acquired at the end of the ablation season. Specifically, we computed the median and NMAD of the elevation changes for each of the model elevation band (300 m bands). At last, where available, snow pit measurements are compared to the model and satellite data for the altitude band they belong to.

\section{RESUlts}

The InSAR processing was applied to all TDX pairs, producing 5 new DEMs of the Mont-Blanc area over a one and half year period. In the ascending configuration, the DEMs cover approximately $2 / 3$ of the study area (i.e the Pléiades 2012/08/19 DEM extent), whereas in the descending configuration, they cover half of the study area (Table III). Most gaps are due to areas of shadow and layover.

\section{A. Uncertainty of the TanDEM-X DEMs}

In order to estimate the uncertainty of the TDX DEMs, we computed the difference between each TDX DEM and the Pléiades 2012 DEM below 2000 m a.s.1., at the exclusion of glaciers, vegetated areas, and slopes higher than $40^{\circ}$. The results are summarized in Table III. The February and May TDX DEMs have a positive bias (1-2 m) compared to Pléiades, due to the presence of wet snow at low elevations (cf Figure 3). However, for the autumn DEMs that are snow free at these elevations, there is no significant bias, which confirms the good vertical alignment. The NMAD of the residuals lies in the range of 1-3 m, similar to previous studies on glaciers [5]. The February pair has slightly larger residuals which we attribute to the spatial variations in snow cover. We did not find any significant difference in uncertainty with the incidence angle or perpendicular baseline.

\section{B. Off-ice elevation changes}

We first analyse the average elevation changes observed off ice. Figure 3 (black bars) shows the office elevation difference between each TDX DEM and 
TABLE III. StATISTICAL ESTIMATION OF THE ELEVATION DiFFERENCES BETWEEN THE RADAR AND OPTICAL DEMS (TDX PlÉIADES) BELOW 2000 M, EXCLUDING GLACIERS, VEGETATION AND SLOPES HIGHER THAN 40 - DEM COVERAGE (PERCENTAGE OF THE PLÉIAdES 2012/08/19 DEM EXTENT).

\begin{tabular}{|l|c|c|c|c|c|}
\hline & \multicolumn{2}{|c|}{ Reference } & \multicolumn{2}{c|}{ Pléiades 2013/09/20 } & \\
\hline \multirow{2}{*}{ TDX Pair } & Median (m) & NMAD (m) & Median (m) & NMAD (m) & Coverage (\%) \\
$2012 / 05 / 13$ & 1.58 & 2.01 & 1.06 & 1.80 & 68 \\
$2013 / 02 / 01$ & 1.28 & 1.83 & 0.86 & 1.62 & 68 \\
$2013 / 10 / 21$ & 2.01 & 2.55 & 1.79 & 2.71 & 69 \\
$2013 / 11 / 12$ & 0.07 & 1.34 & 0.04 & 1.36 & 49 \\
\hline
\end{tabular}

the Pléiades 2013 DEM, for 5 altitude bands (except for $3600 \mathrm{~m}$ a.s.l. where not enough off-ice points are available). At $1200 \mathrm{~m}$ a.s.l., all DEMs measure a close to $0 \mathrm{~m}$ elevation change, which is coherent with the absence of snow (red and blue lines) at this elevation, except for February. For this month, some snow may be present, but the vertical alignment of the optical and radar DEM below $1500 \mathrm{~m}$ a.s.l constrained the median difference to 0 . As a consequence, a small vertical shift $(<1 \mathrm{~m})$ can be expected for this DEM, and the use of identified snow-free areas would be required for a finer alignment, which was not performed in this study. For the May 2012 DEMs, the elevation difference increases with altitude, and reaches 5-6 m above $3000 \mathrm{~m}$ a.s.1.. This is coherent with the modelled snow height and the wet conditions at this period of the year which implies a scattering of the radar signal at the snow surface. The elevation changes observed by TDX overestimate the modelled snow height above $2400 \mathrm{~m}$ a.s.1., but are in good agreement with the snow pit measurements (green bars). At high altitude, the meteorological analysis system SAFRAN is known to underestimate seasonal snowfall [40] which may explain the underestimation of snow depth by Crocus when compared to snow pit measurements. For the February and autumn DEMs (2013), the observations agree within error bars to the modelled snow height below $3000 \mathrm{~m}$ a.s.l.. Above this altitude, the snowpack is very likely dry as simulated by the model and the X-band radar can penetrate in the snow. This is the reason why the TDX DEMs underestimate the actual elevation. At last, no significant relationship was found between elevation changes and terrain aspect over the study area, probably because of the impact of projected shadows.

To summarize, below $\sim 2500 \mathrm{~m}$ a.s.l. for the dates of our study, the presence of wet snow at the top of the snowpack implies that TDX measures the snow surface. On average, for $300 \mathrm{~m}$ altitude bands, the elevation measured by TDX agrees with the observed and modelled snow height, with an uncertainty of 1$2 \mathrm{~m}$. Above $\sim 2500 \mathrm{~m}$ a.s.1., dry snow is dominant at the top of the snowpack from October until AprilMay and penetration is very likely to occur, causing an underestimation of the snow surface in the TDX DEMs.

\section{Glacier elevation changes}

Figure $4 \mathrm{a}$ shows the temporal evolution of the Mer de Glace surface, with reference to the Pléiades 2013 DEM, as a function of altitude. As shown in the previous section, below $\sim 2500 \mathrm{~m}$ a.s.1, the presence of wet snow at the surface allows TDX to see the actual surface. In particular, for the February 2013 pair, the presence of wet snow is indicated by a lowering of the backscatter of over $3 \mathrm{~dB}$ [25] below $2000 \mathrm{~m}$ a.s.1, concomitant with an increase of the surface elevation between August 2012 and February 2013 (Figure 4a). At these low elevations, 


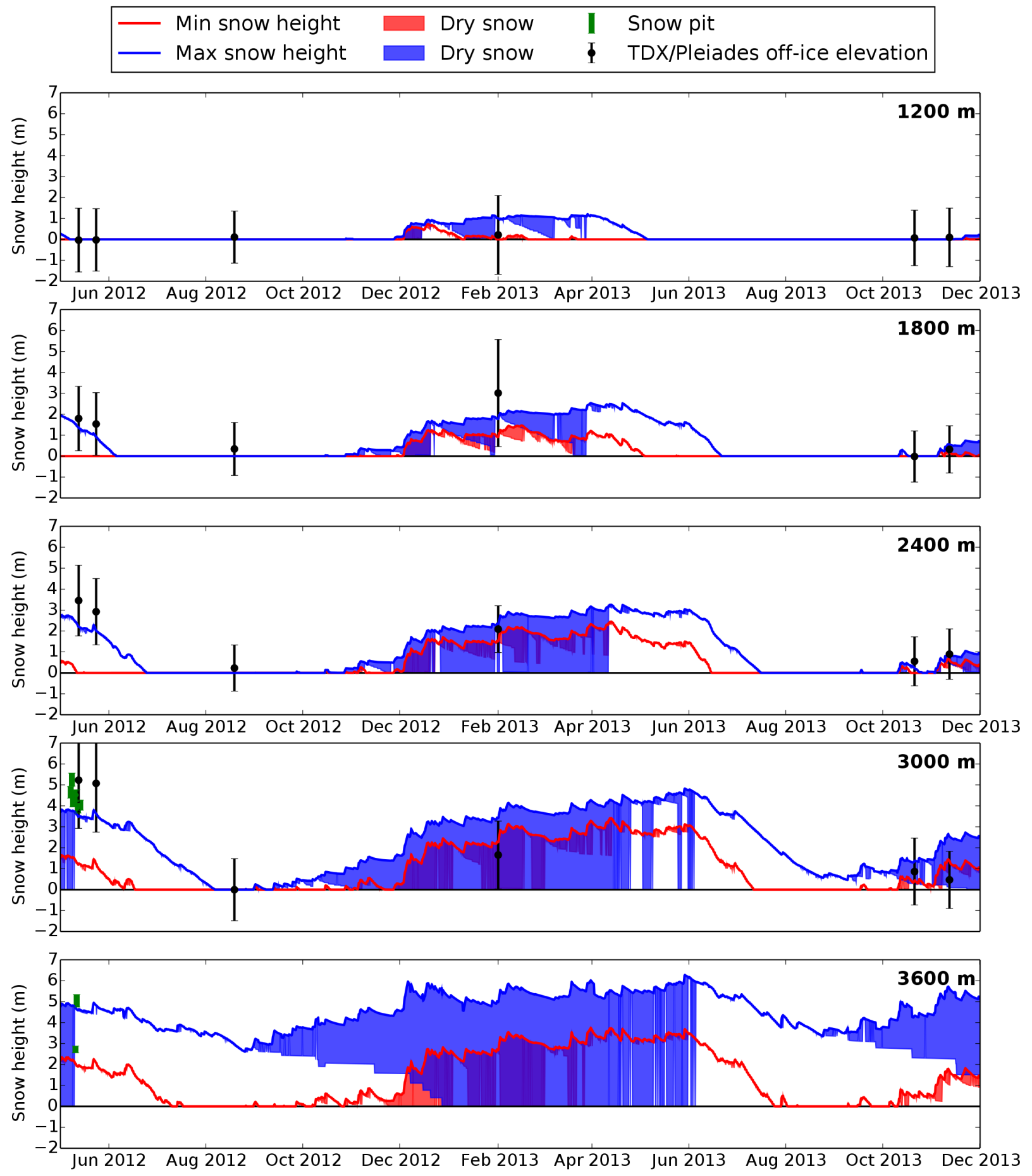

Fig. 3. Temporal evolution of the snowpack for the study period over the Mont-Blanc massif at 5 selected altitude bands, as simulated by the Crocus model. Blue and red lines show the maximum ( north slopes) and minimum ( south slopes) snow height, for snow aged less than a year. Red/blue shadings show the top dry snow layers, that are potentially penetrated by the X-band radar. Black dots and error bars show the median +/- NMAD of the off ice elevation differences with the Pléiades 2013 DEM, for each available DEM (5 TDX + Pléiades 2012) and a $300 \mathrm{~m}$ altitude band around the central altitude (at $3600 \mathrm{~m}$ a.s.l., no off-ice difference is available). Green bars represent ground measurements of accumulation on May 10-11 2012 for this altitude band (y extent shows uncertainty, x positions are slightly shifted to separate all measurements). 
we observe the thinning of the Mer de Glace tongue by $12 \mathrm{~m}$ between May 2012 and November 2013 (2 ablation seasons). This is consistent with the thinning rate reported by several studies [20, 22]. It is also noteworthy that the TDX DEMs derived from images acquired only 11 or 22 days apart (May 13 - 24 and October 21 - November 12) are in good agreement over the whole altitude range.

At higher elevations, the radar signal penetrates the snowpack and TDX does not see the snow/firn surface anymore. The difference between the two May DEMs (blue lines) above $3500 \mathrm{~m}$ a.s.l. can be explained by a humidification of the top snow layers (Figure 3) and thus a change in penetration between the two dates. This is indicated by a strong lowering in the radar backscatter between May 13 and May 24 of over 3 $\mathrm{dB}$ (Figure 4b), indicating wet snow. Above $3000 \mathrm{~m}$ a.s.l., the February DEM (green line) is well below the surface observed by Pléiades 2012 (blue dotted line) 5.5 months before. This difference is very likely the sum of the radar penetration into the dry snow (as confirmed by the model) and the subsidence of the surface due to the glacier dynamics over this 5.5 months period. At last, the 2013/10/21 TDX DEM (yellow line) shows a good agreement with Pléiades 2013 acquired only 31 days earlier, at all altitudes below $3500 \mathrm{~m}$ a.s.1., but shows signs of penetration again above this altitude, as indicated by a high backscatter coefficient and thus dry snow (Figure 4b).

\section{X-band interferometric bias}

Thanks to the close acquisition of Pléiades 2013/09/20 and TDX 2013/10/21 (31 days difference, a time span over which glacier elevation changes are assumed to be negligible), we are able to estimate the difference between the optical and radar DEMs, and thus the interferometric penetration depth of the microwave signal. Figure 5a shows that the two DEMs are in very good agreement overall, except in regions
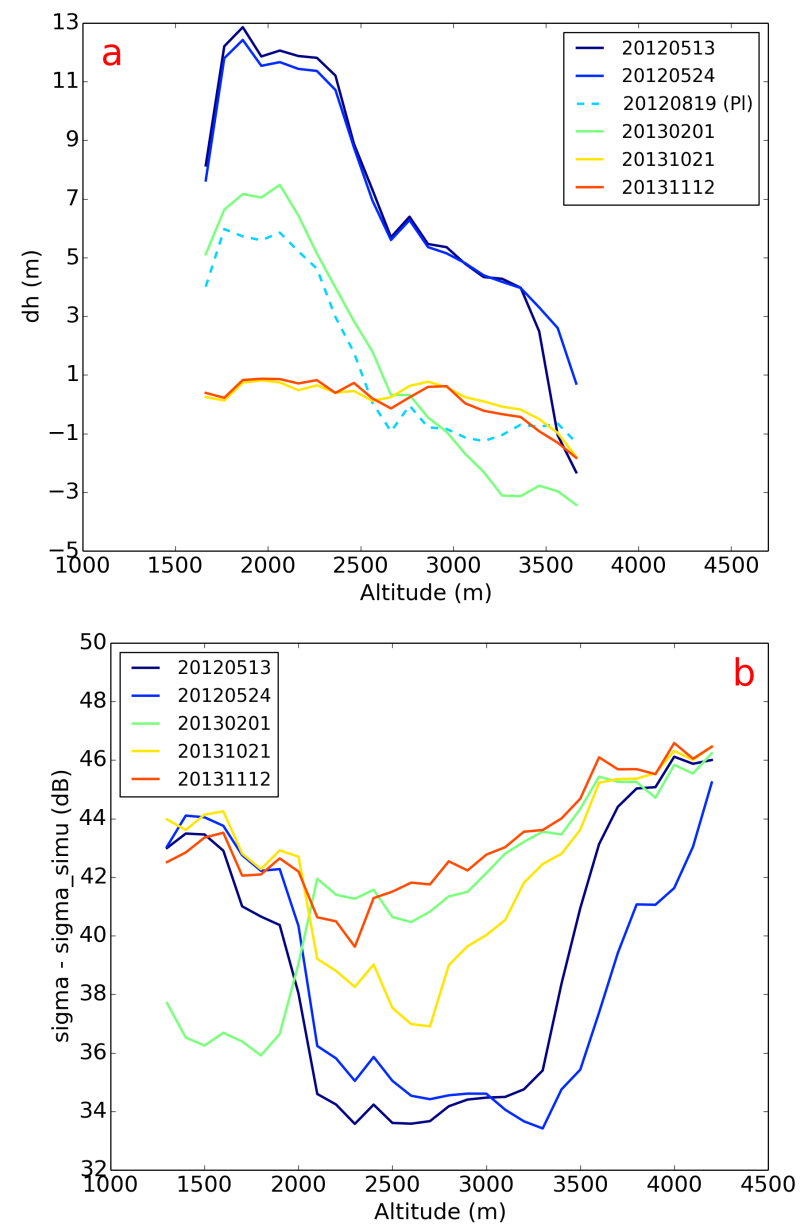

Fig. 4. (a) Median of the elevation difference between each available DEM (5 TDX + Pléiades 2012 (noted Pl)) and the Pléiades 2013/09/20 DEM, computed for $100 \mathrm{~m}$ altitude bins, on the Mer de Glace. Positive values indicate elevations higher than the Pléiades 20130920 DEM. (b) Median value of the flattened backscatter, in decibels, for $100 \mathrm{~m}$ altitude bins, and each of the TDX pairs, for all glaciers. The flattened backscatter is the ratio of the measured backscatter (sigma), divided by the backscatter simulated from the reference DEM (sigma_simu). This "flattening" is necessary in order to remove the effect of the terrain slope/aspect in the backscatter value.

of forest and vegetation (red dots in Chamonix valley, upper left) and at high altitude (>3500 m), especially on the northen slopes of the Mont-Blanc summit, where the difference can reach 6-7 m. At $4000 \mathrm{~m}$ a.s.l. it is on average $4 \mathrm{~m}$. This is very likely due to the radar penetration in snow, which is dry at these altitudes and 
for northern slopes, as confirmed by Figure 3.

Figure $5 \mathrm{~b}$ shows the difference between the TDX 2013/02/01 DEM and Pléiades 2012/08/19 DEM. Off ice, negative differences are visible again in vegetated areas and a positive difference of $2-3 \mathrm{~m}$ is visible at medium altitudes due to the wet snow cover in February. On glaciers, at altitudes higher than $3000 \mathrm{~m}$ a.s.1., the TDX DEM is lower than the Pléiades DEM by 3-6 $\mathrm{m}$. This can be explained by several factors. First of all, as confirmed by the model (Figure 3), in February and at altitudes above $3000 \mathrm{~m}$ a.s.1, the snowpack experience consistently dry conditions for all snow layers. This means that the radar potentially penetrates through the snow accumulated since the last ablation season. Secondly, the ice flow causes the snow layers to subside above the equilibrium line, which is situated at approximately $2900 \mathrm{~m}$ in this area [41]. For a steady state glacier, the submergence velocity must compensate for the accumulation over a year, so that the surface remains at the same elevation from year to year. Even if the glacier is unbalanced, this approximation can be considered as nearly true, as shown by ground measurements in this region [42]. We can estimate the submergence over the 5.5 months interval as about half of the yearly accumulation, i.e 2-3 $\mathrm{m}$ according to Figure 3. This is in good agreement with the average elevation difference observed at high altitudes, even though it varies spatially due to the local slope and snowpack conditions.

\section{E. Impact on geodetic mass balances}

In order to estimate the impact of this interferometric bias on geodetic glacier mass balances, we derived the volume change between the TDX 2013/10/21 and Pléiades 2013/09/20 DEMs for the Mer de Glace and Bossons glaciers and convert it to a mass change assuming an ice density of $850 \pm 60 \mathrm{~kg} \cdot \mathrm{m}^{-3}$ [43]. The elevation difference (Figure 6, black dots) has a similar profile with altitude for the two glaciers, with a maxi- mum of approximately $4 \mathrm{~m}$ above $4000 \mathrm{~m}$ a.s.l. These elevation differences are then converted to an equivalent volume change by multiplying them with the glacier hypsometry (red/blue histograms). A slight volume gain is measured at altitudes below $3000 \mathrm{~m}$ a.s.l likely due to snow falls during the 31 days interval (Figure 3) and is excluded from the analysis. The volume loss above 3000 $\mathrm{m}$ a.s.l. are considered to be due to the radar penetration in snow/firn as the ablation or the submergence are negligible over 31 days. Snow falls may have occurred over this period but are transparent to the radar signal, otherwise the surface measured by TDX would be above the Pléiades surface. Thus, we conclude that if the TDX DEM is the most recent DEM, geodetic mass balances would have a systematic error of approximately -0.23 $\mathrm{m}$ w.e. for the Mer de Glace and $-1.66 \mathrm{~m}$ w.e. for the Bossons glacier. The value depends on each individual glacier's hypsometry, but the two cases shown here give a broad interval of this uncertainty for the western Alps, Mer de Glace being considered as a best case with most of its accumulation area below $3600 \mathrm{~m}$ a.s.l and Bossons glacier being a least favourable case with its accumulation area mostly above $3800 \mathrm{~m}$ a.s.l and reaching the Mont-Blanc summit, the highest top in the western Alps.

\section{Discussion}

\section{A. Impact of the X-band penetration on geodetic mass balances}

The 4-6 $\mathrm{m}$ penetration bias observed in October and February above $4000 \mathrm{~m}$ a.s.l. is similar to the values of 3.7-5.7 m obtained on the Antarctic margin comparing TDX elevation with IceBridge (LIDAR) dataset [14]. The mean annual air temperature and englacial temperature at $4250 \mathrm{~m}$ (col du Dôme) is around $-11^{\circ} \mathrm{C}$ and remains mostly below freezing level [42]. Thus melting is close to zero and conditions similar to the Antarctic margin can be expected. In addition, the snow/firn pack is several tens of meters deep (Figure 4 in reference 

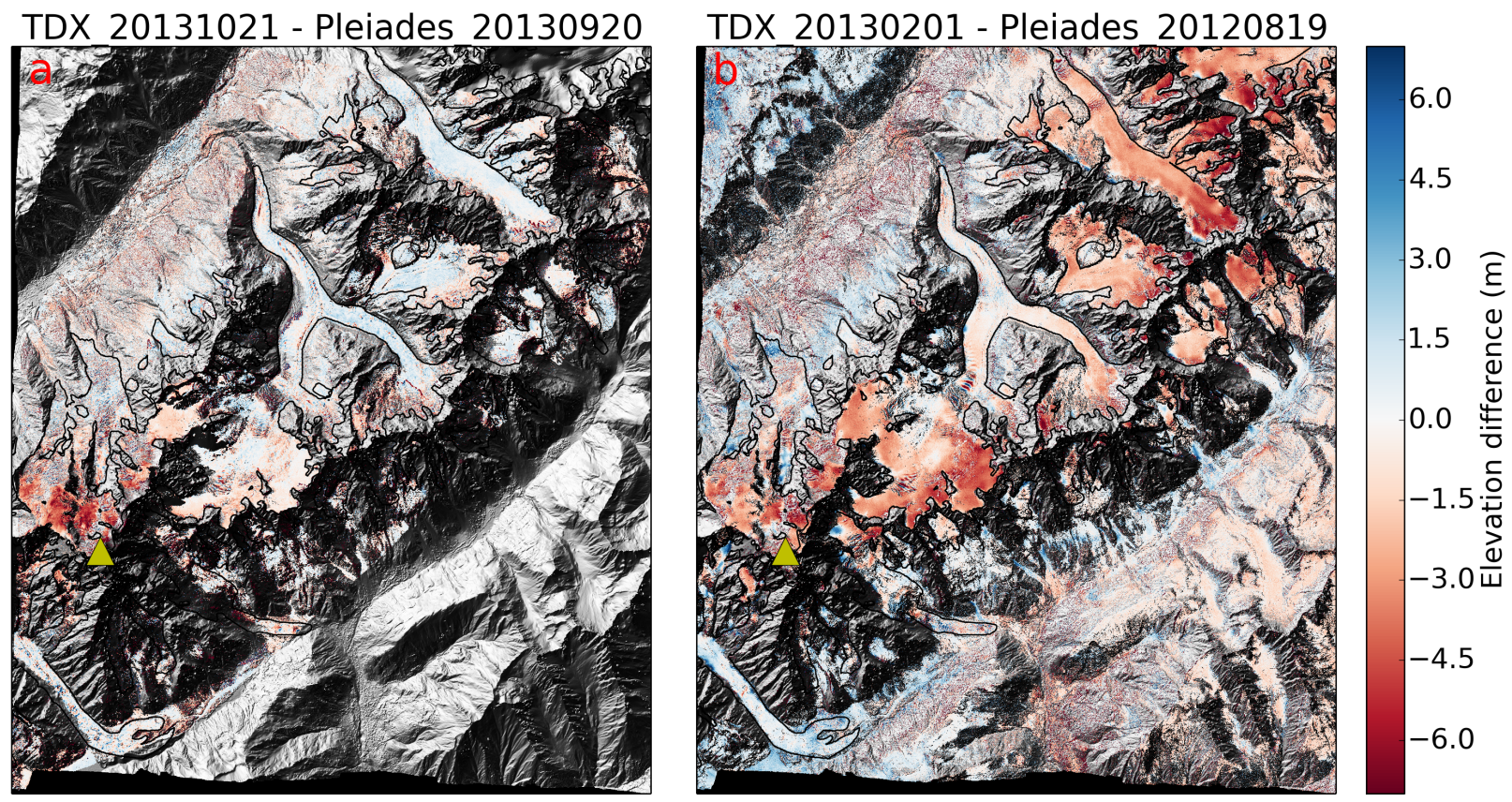

Fig. 5. Elevation difference between (a) TDX 2013/10/21 and Pléiades 2013/09/20 DEMs, (b) TDX 2013/02/01 and Pléiades 2012/08/19 DEMs. Positive values indicate that TDX is above Pléiades. The Mont-Blanc summit $(4810 \mathrm{~m})$ is marked with a yellow triangle. The background is a shaded relief of the Pléiades 2012 DEM.

[42]). As a consequence, penetration of several meters can be expected at these very high elevations.

The uncertainty associated with this interferometric bias on a geodetic mass balance has been estimated for the X-band October DEM and a worst case scenario, the highly elevated Bossons glacier, to -1.66 m.w.e if the radar DEM is the most recent. This uncertainty is too large to derive an accurate annual mass balance. However, if integrated over a period of for example 10 years, a standard practice in glaciology in order to reduce uncertainties in ice density [43], the error would be at most $-0.17 \mathrm{~m}$ w.e. $\mathrm{yr}^{-1}$. This error is significant and should be taken into account when deriving mass balances from X-band DEMs. But it remains in the range of elevation changes uncertainties (Rankl and Braun [8] found $\sim 0.10 \mathrm{~m} \mathrm{w.e.yr}^{-1}$, Fischer et al. [44] found $0.02-0.36 \mathrm{~m}^{\mathrm{w}}$.e. $\mathrm{yr}^{-1}$ ) or seasonality correction when using DEMs acquired at different seasons $(\sim 0.15$ $\mathrm{m}$ w.e. $\left.\mathrm{yr}^{-1}[15]\right)$.

Unfortunately, as no Pléiades DEM is available in winter for the studied period, we are not able to make a similar error estimate in winter, but it is very likely to be much higher than in autumn, as suggested by Figure 5b. This can, for example, induce a strong bias in geodetic glacier mass balances when one of the DEMs is SRTM. Indeed, the SRTM DEM has been acquired in February 2000, in C-band that should penetrates even deeper than the X-band data analysed here [44]. It will also cause a significant error if using two radar DEMs acquired under different snow conditions or during different phases of the annual accumulation/melt cycle of glaciers. On the contrary, it would be minimized when differencing two radar DEMs acquired at the same time of year, with similar snow and ice conditions, and in the same radar band (e.g like in $[5,8]$ ), but over this area, no other X-band DEM is available for comparison. 

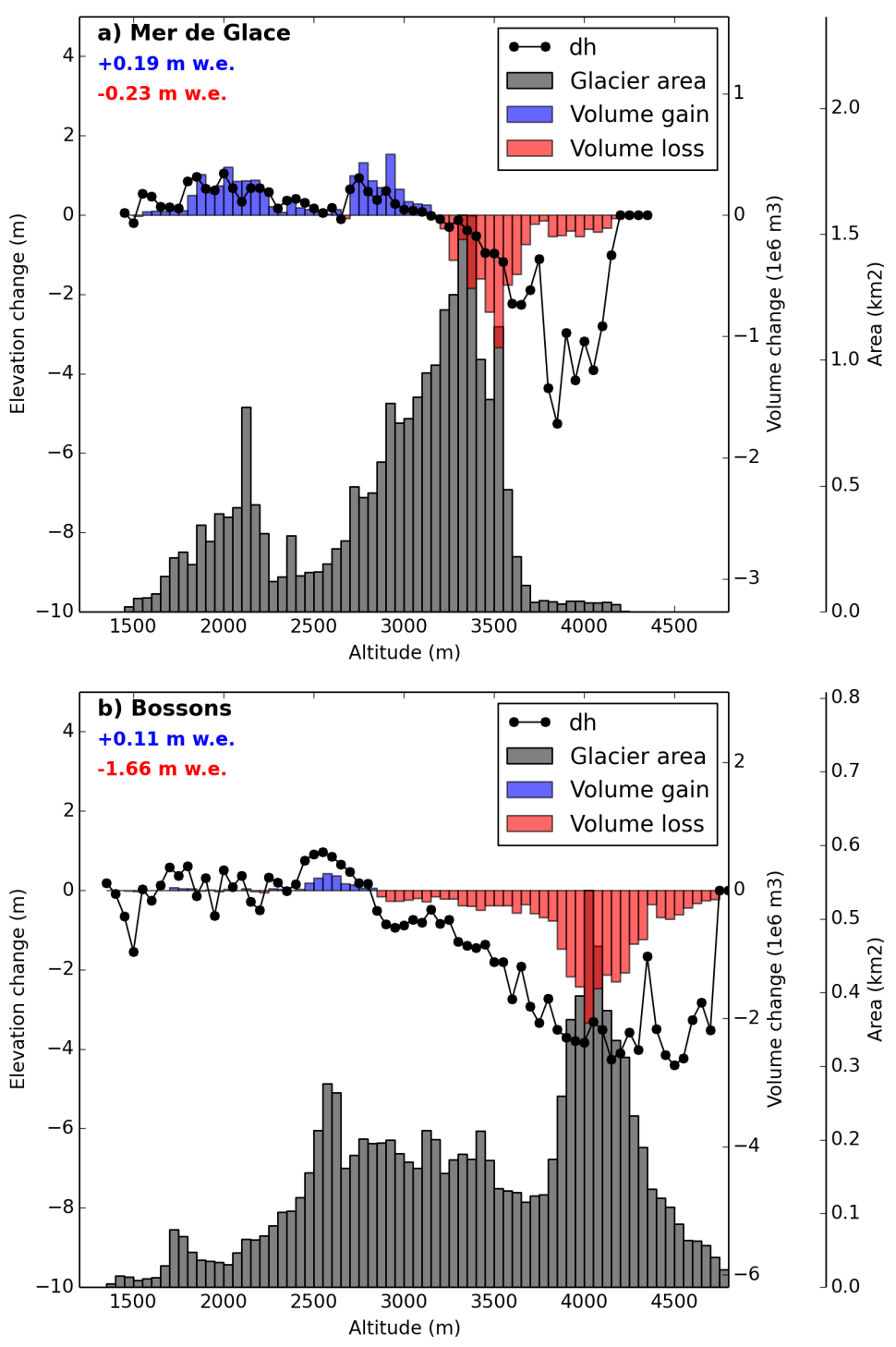

Fig. 6. Median elevation difference (black dots) between TDX 2013/10/21 and Pléiades 2013/09/20, glacier area (grey) and associated volume gain/loss (blue/red histogram) for $50 \mathrm{~m}$ bins, for (a) the Mer de Glace and (b) Bossons glaciers. The sum of all gains/loss is displayed on the upper left corner of each graph in blue/red, expressed in $m$ w.e.

At last, as shown by the model, at these altitudes, the snowpack conditions are rather stable in autumn and February, we thus consider that these values are representative of the average interferometric bias during these seasons. But similar studies in areas with different climatic conditions are now necessary in order to generalize these conclusions.

\section{B. Impact of the reference DEM}

In this region of high-relief topography, a reference DEM is required during the unwrapping stage. Indeed, frequent areas of shadow/layover create interruptions in the phase of the interferogram throughout the image (Figure 7, left), and the absolute phase must be retrieved for all the disconnected patches, thus increasing the chances of phase errors. Using the 
Pléiades 2012 DEM as a reference, with a date of acquisition and resolution close to TDX, minimized the chances of phase unwrapping errors. But such a high-resolution DEM is not available everywhere on Earth. Thus, in order to test the impact of the reference DEM on the TDX DEM quality and uncertainty, we applied the same processing using the SRTM DEM as a reference during the unwrapping stage. In this section, we first assess the presence of unwrapping errors in the final DEM and discuss the choice of an ideal reference DEM. We then estimate the impact of the reference DEM on the TDX DEM uncertainty, after correcting for the unwrapping errors.

Figure 7 (right) shows the difference between the TDX DEMs obtained using Pléiades $\left(\mathrm{TDX}_{\mathrm{Pl}}\right)$ and SRTM $\left(\right.$ TDX $\left._{\mathrm{SRTM}}\right)$ as a reference, for the pair 2012/05/13. Unwrapping errors are clearly identifiable with differences larger than $15 \mathrm{~m}$. As shown by the histogram, the differences are concentrated around multiples of the HoA. We detected these unwrapping errors by comparing the TDX DEMs to the Pléiades 2012 DEM. Because the time separation between each TDX pair and the Pléiades DEM is short, any difference larger than half of the HoA (i.e., $15 \mathrm{~m}$ to $30 \mathrm{~m}$ for our TDX pairs) is assumed to be an unwrapping error. The fractions of the image with unwrapping errors for the two reference DEMs and each TDX pair are summarized in Table IV. About 1-3\% unwrapping errors occur when using Pléiades as a reference. These errors are essentially isolated pixels in areas of low coherence. These errors can be easily filtered at post-processing, either by applying a median filter or excluding pixels with a coherence below 0.7. This latter reduces the percentage of unwrapping errors to less than $1 \%$ when using Pléiades as a reference (Table IV, second line).

On the contrary, using SRTM as a reference, up to $23 \%$ of the TDX DEM is impacted by unwrapping errors for this very rugged topography. Unwrapping errors are more likely in the ascending configuration because shadow/layover are more frequent in the study area due to the (ascending) imaging geometry. The first source of error is the large elevation changes caused by the large time separation of 12-13 years between SRTM and the TDX pairs, compared to Pléiades. On glaciers, changes in the range of several tens of meters, corresponding to a few fringes, are frequent over this period. The second source of errors is probably aliasing. Even though the SRTM DEM is bilinearly interpolated at a resolution close to TDX, the $30 \mathrm{~m}$ resolution is not good enough to capture some of the strong elevation gradients. Moreover, the SRTM DEM is void filled with the ASTER DEM generated from optical data and this creates even more chances of aliasing at the edges of the voids.

The very difficult topography (altitude range of $\sim 4000 \mathrm{~m}$ ) and the unfavourable geometry of the TDX acquisitions (particularly in ascending configuration) over the study area make the phase unwrapping very challenging in this study and it can rather be seen as an exception compared to most topographies on Earth. Nevertheless, in order to reduce the risk of unwrapping errors, it is recommended to use a reference DEM that is as close in time and in resolution as possible to the TDX acquisitions. Another solution to be completely independent of an external DEM would be to first produce a reference DEM by combining several TDX acquisitions using the dual-baseline approach, then unwrap the difference between each single pair and the reference DEM, in areas of rapid changes such as glaciers. Moreover, some precautions during the processing must be taken to limit unwrapping errors, such as multi-looking or keeping a low coherence threshold, to avoid breaking paths to some parts of the image during the unwrapping stage. When phase discontinuities exist, the unwrapping cannot be performed continuously over the entire image and the only solution is to estimate the absolute phase of the 
interferogram. This can be done with methods using coherence tracking or Split-Band InSAR [45, 46]. The drawback of the method is a reduction in the resolution of the final output. But it could be used to first estimate the absolute height of at least one pixel for each connected component, before unwrapping the full image. This method has been recently applied to estimate the absolute altitude of the central crater of the Nyiragongo volcano using TDX data [47]. Unfortunately, they could not reach a vertical accuracy better than 3 fringes, similar to the errors we observe here.

In a second step, we corrected the unwrapping errors and estimated the uncertainty associated with the use of different reference DEMs. The phase unwrapping allows estimating the phase difference between two adjacent pixels and therefore any connected pixels. But it fails when two areas are disconnected by shadow/layover. The absolute phase of each disconnected areas was hence estimated by choosing, for each pixel, the integer number of $2 \pi$ values that minimizes the difference between the TDX and Pléiades DEMs. This method works only because the elevation difference with Pléiades can be assumed to be less than half of the height of ambiguity. In practice, it means moving all the minor modes of the histograms seen on the inset of Figure 7 to the main mode. This correction allows us to compare the DEMs obtained using Pléiades or SRTM as a reference. The elevation difference between the two DEMs is symmetrically distributed around 0 (Table $\mathrm{V}$ ) which means that the reference DEM did not induce a bias. The NMAD of the difference range from 1.69 to $2.58 \mathrm{~m}$, which is in the range of the DEMs uncertainty. These differences are particularly visible on small scale features such as glaciers crevasses or buildings. It has to be noted that the NMAD increases with the HoA, with values of $4-6 \%$ of the HoA (Table V). As a test to identify the source of these differences, we processed the TDX data without the adaptive interferogram filtering (which decreases the quality of the final result). In this case, the results obtained using Pléiades or SRTM as a reference are exactly the same (at the exception of numerical rounding errors of $\sim 1 e^{-6} \mathrm{~m}$ ) after correcting for the phase jumps. This means that the differences between $\mathrm{TDX}_{\mathrm{Pl}}$ and $\mathrm{TDX}_{\mathrm{SRTM}}$ are only caused by the adaptive filtering of the interferogram and not introduced by the reference DEM.

In summary, the reference DEM does not seem to introduce any significant difference in the final TDX DEM, at the exception of unwrapping errors.

\section{CONCLUSIONS AND PERSPECTIVES}

In this study, we derived 5 new DEMs of the MontBlanc area from TanDEM-X data acquired between May 2012 and November 2013. A high resolution Pléiades DEM acquired in August 2012 was used as a reference during the phase unwrapping to avoid phase jumps between areas disconnected by shadows/layovers. The vertical precision estimated with reference to the Pléiades DEM over ice and snow free areas and slopes less than $40^{\circ}$ was in the range of 1-3 m. TanDEM-X is thus a potential alternative to optical sensors such as Pléiades, with the benefits of a global coverage and the all-weather operating, but the penetration of the radar signal in dry snow and firn should be taken into account. The comparison with Pléiades DEMs shows that in the Alps, the interferometric bias induced by radar penetration can reach $6 \mathrm{~m}$ in October but is limited to elevations higher than $3500 \mathrm{~m}$, with a mean value of 4 $\mathrm{m}$ at $4000 \mathrm{~m}$ a.s.1. The systematic error induced by this $\mathrm{X}$-band penetration on a geodetic mass balance has been estimated to $-0.23 \mathrm{~m}$ w.e. for the Mer de Glace and -1.66 $\mathrm{m}$ w.e. for the Bossons glaciers. This error depend on the glacier hypsometry but the Bossons glacier can be considered as a worst case scenario for this region, with an accumulation area mainly above $3800 \mathrm{~m}$ a.s.1 and reaching the top of the Mont-Blanc. This error limits 

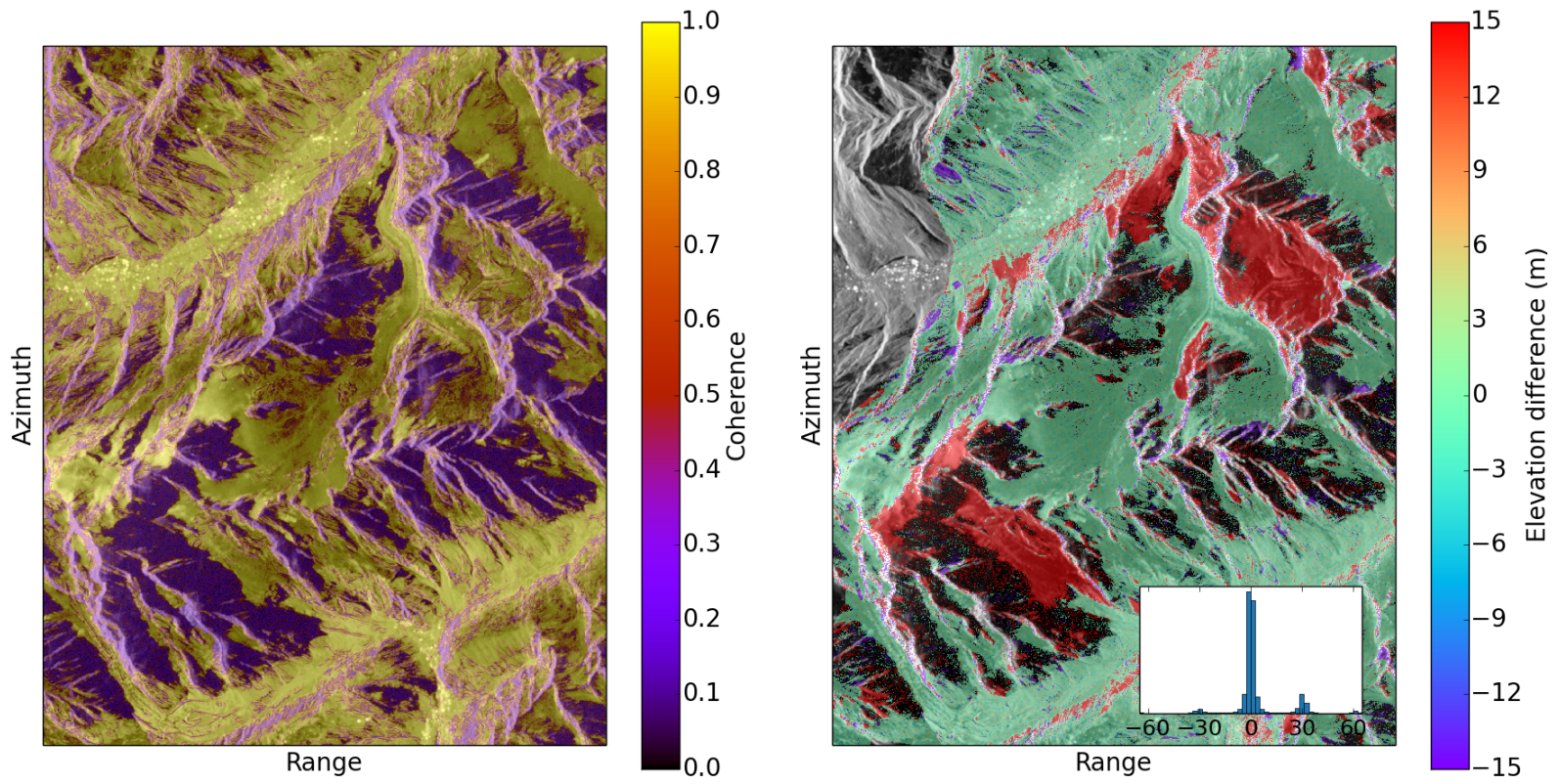

Fig. 7. Interferometric coherence (left) and elevation difference with Pléiades 2013 (right) for the TDX pair 2012/05/13 (HoA=30.3 m) unwrapped with SRTM as a reference, in the radar geometry. Inset shows the histogram of the elevation differences. Background is the amplitude image : dark regions are areas of shadow, very bright regions are areas of layover. Areas disconnected from the rest of the image due to shadow/layover (low coherence) tend to have more unwrapping errors (in purple/red in the right image).

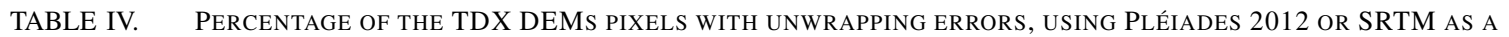
REFERENCE FOR PHASE UNWRAPPING.

\begin{tabular}{|c|c|c|c|c|c|}
\hline Reference DEM (coherence threshold) & $2012 / 05 / 13$ & $2012 / 05 / 24$ & $2013 / 02 / 01$ & $2013 / 10 / 21$ & $2013 / 11 / 12$ \\
\hline Pléiades 2012 (CO $>0.3)$ & $2.5 \%$ & $2.7 \%$ & $1.2 \%$ & $0.7 \%$ & $1.4 \%$ \\
Pléiades 2012 (CO >0.7) & $0.6 \%$ & $0.5 \%$ & $0.2 \%$ & $0.1 \%$ & $0.2 \%$ \\
SRTM (CO $>0.3)$ & $22.8 \%$ & $21.9 \%$ & $10.0 \%$ & $5.3 \%$ & $6.0 \%$ \\
SRTM (CO $>0.7)$ & $18.1 \%$ & $17.0 \%$ & $6.8 \%$ & $3.4 \%$ & $3.7 \%$ \\
\hline
\end{tabular}

TABLE V. ElEVATION DifFERENCES BETWEen two TDX DEMs obTAINED USING EITHER PléiAdes 2012 OR SRTM AS A REFERENCE FOR THE PHASE UNWRAPPING.

\begin{tabular}{|c|c|c|c|c|c|}
\hline & $2012 / 05 / 13$ & $2012 / 05 / 24$ & $2013 / 02 / 01$ & $2013 / 10 / 21$ & $2013 / 11 / 12$ \\
\hline Median (m) & -0.05 & -0.05 & -0.13 & -0.09 & -0.09 \\
NMAD (m) & 1.69 & 1.70 & 2.58 & 2.42 & 2.43 \\
NMAD/HoA & 0.055 & 0.054 & 0.044 & 0.037 & 0.038 \\
\hline
\end{tabular}


the use of radar data to derive annual mass balances, but is acceptable for mass balances derived over a typical 10-year period. Nevertheless, more studies, on different areas with different climatic conditions are necessary in order to generalize this assertion. The TDX DEM obtained for February shows that the error due to penetration into snow is very likely larger for radar derived DEMs acquired during winter.

At last, the same processing has been conducted using the medium resolution SRTM DEM as a reference for the unwrapping. In this very difficult terrain, shadow/layover caused many areas to be disconnected during the unwrapping stage and many phase ambiguities could not be solved correctly. Much care must be taken when unwrapping TDX differential singlepass interferograms with the use of a lower resolution DEM, particularly if changes larger than the height of ambiguity are expected between the two acquisitions. Nevertheless, we showed that the accuracy of the final DEM was not significantly impacted by the reference DEM.

\section{ACKNOWLEDGMENTS}

Precise comments and suggestions of anonymous reviewers greatly improved the quality of the paper. The authors would like to thank the German Aerospace Center (DLR) for providing the data, through the projects \#GLAC0874 and gourmele_XTI_GLAC0296, and the French Space Agency (CNES) for supporting this research through the TOSCA-CESTENG and TOSCATOP GLACIER projects. This work was supported by the Programme National de Télédétection Spatiale (PNTS, http://www.insu.cnrs.fr/pnts), grant $\mathrm{n}^{\circ}$ PNTS2016-01. Pléiades images were acquired during the CNES Pléiades thematic commissioning phase. A. Dehecq acknowledges a PhD fellowship from CNES and the Assemblée des Pays de Savoie (APS).

\section{REFERENCES}

[1] M. Zink, G. Krieger, H. Fiedler, and A. Moreira, "The TanDEM-X mission: Overview and status," in Geoscience and Remote Sensing Symposium, 2007. IGARSS 2007. IEEE International. IEEE, 2007, pp. 3944-3947. [Online]. Available: http://ieeexplore.ieee.org/xpls/ abs_all.jsp?arnumber $=4423711$

[2] C. Rossi, F. R. Gonzalez, T. Fritz, N. Yague-Martinez, and M. Eineder, "TanDEM$\mathrm{X}$ calibrated Raw DEM generation," ISPRS Journal of Photogrammetry and Remote Sensing, vol. 73, pp. 12-20, 2012. [Online]. Available: http://www.sciencedirect.com/science/ article/pii/S0924271612001062

[3] M. Lachaise, U. Balss, T. Fritz, and H. Breit, "The dual-baseline interferometric processing chain for the TanDEM-X mission," in Geoscience and Remote Sensing Symposium (IGARSS), 2012 IEEE International, Jul. 2012, pp. 5562-5565.

[4] M. Eineder, W. Jaber, D. Floricioiu, H. Rott, and N. Yague-Martinez, "Glacier flow and topography measurements with TerraSar-X and TanDEM-X," in Geoscience and Remote Sensing Symposium (IGARSS), 2011 IEEE International, Jul. 2011, pp. 3835-3838.

[5] N. Neckel, A. Braun, J. Kropáček, and V. Hochschild, "Recent mass balance of the Purogangri Ice Cap, central Tibetan Plateau, by means of differential X-band SAR interferometry," The Cryosphere, vol. 7, no. 5, pp. 1623-1633, Oct. 2013. [Online]. Available: http://www.the-cryosphere.net/7/1623/2013/

[6] W. A. Jaber, D. Floricioiu, H. Rott, and M. Eineder, "Surface elevation changes of glaciers derived from SRTM and TanDEM-X DEM differences," in Geoscience and Remote Sensing Symposium (IGARSS), 2013 IEEE International, Jul. 
2013, pp. 1893-1896.

[7] H. Rott, D. Floricioiu, J. Wuite, S. Scheiblauer, T. Nagler, and M. Kern, "Mass changes of outlet glaciers along the Nordensjköld Coast, northern Antarctic Peninsula, based on TanDEMX satellite measurements," Geophysical Research Letters, vol. 41, no. 22, p. 2014GL061613, Nov. 2014. [Online]. Available: http://onlinelibrary. wiley.com/doi/10.1002/2014GL061613/abstract

[8] M. Rankl and M. Braun, "Glacier elevation and mass changes over the central Karakoram region estimated from TanDEM$\mathrm{X}$ and SRTM/X-SAR digital elevation models," Annals of Glaciology, vol. 57, no. 71, pp. 273-281, 2015. [Online]. Available: http://www.ingentaconnect.com/content/ igsoc/agl/pre-prints/content-ings_agl_71a024

[9] H. Rott, K. Sturm, and H. Miller, "Active and passive microwave signatures of Antarctic firn by means of field measurements and satellite data," Ann Glaciol, 1993. [Online]. Available: http://epic.awi.de/2674

[10] P. Lacroix, B. Legrésy, R. Coleman, M. Dechambre, and F. Rémy, "Dual-frequency altimeter signal from Envisat on the Amery ice-shelf," Remote Sensing of Environment, vol. 109, no. 3, pp. 285-294, Aug. 2007. [Online]. Available: http://linkinghub.elsevier.com/retrieve/ pii/S0034425707000442

[11] J. Dall, "InSAR Elevation Bias Caused by Penetration Into Uniform Volumes," IEEE Transactions on Geoscience and Remote Sensing, vol. 45, no. 7, pp. 2319-2324, Jul. 2007.

[12] E. Rignot, K. Echelmeyer, and W. Krabill, "Penetration depth of interferometric syntheticaperture radar signals in snow and ice," Geophysical Research Letters, vol. 28, no. 18, pp. 3501-3504, 2001. [Online]. Available: http://ess.uci.edu/researchgrp/erignot/
files/RignotetalGRL2001Penetration.pdf

[13] J. Dall, S. N. Madsen, K. Keller, and R. Forsberg, "Topography and penetration of the Greenland ice sheet measured with airborne SAR interferometry," Geophysical Research Letters, vol. 28, no. 9, pp. 1703-1706, 2001. [Online]. Available: http://onlinelibrary.wiley.com/ doi/10.1029/2000GL011787/pdf

[14] A. Groh, H. Ewert, R. Rosenau, E. Fagiolini, C. Gruber, D. Floricioiu, W. Abdel Jaber, S. Linow, F. Flechtner, M. Eineder, W. Dierking, and R. Dietrich, "Mass, Volume and Velocity of the Antarctic Ice Sheet: Present-Day Changes and Error Effects," Surveys in Geophysics, vol. 35, no. 6, pp. 1481-1505, Nov. 2014. [Online]. Available: http://link.springer.com/10. 1007/s10712-014-9286-y

[15] J. Gardelle, E. Berthier, Y. Arnaud, and A. Kääb, "Region-wide glacier mass balances over the Pamir-Karakoram-Himalaya during 1999-2011," The Cryosphere, vol. 7, no. 4, pp. 12631286, Aug. 2013. [Online]. Available: http: //www.the-cryosphere.net/7/1263/2013/

[16] A. Kääb, D. Treichler, C. Nuth, and E. Berthier, "Brief Communication: Contending estimates of 2003-2008 glacier mass balance over the Pamir-Karakoram-Himalaya," The Cryosphere, vol. 9, no. 2, pp. 557-564, Mar. 2015. [Online]. Available: http://www.the-cryosphere. net/9/557/2015/

[17] M. Barandun, M. Huss, L. Sold, D. Farinotti, E. Azisov, N. Salzmann, R. Usubaliev, A. Merkushkin, and M. Hoelzle, "Re-analysis of seasonal mass balance at Abramov glacier 1968-2014," Journal of Glaciology, vol. 61, no. 230, pp. 1103-1117, Dec. 2015.

[18] C. Vincent, A. Soruco, D. Six, and E. Le Meur, "Glacier thickening and decay analysis from 50 years of glaciological observations performed 
on Glacier d'Argentière, Mont Blanc area, France," Annals of glaciology, vol. 50, no. 50, pp. 73-79, 2009. [Online]. Available: http://www.ingentaconnect.com/content/ igsoc/agl/2009/00000050/00000050/art00011

[19] R. Fallourd, O. Harant, E. Trouvé, J.-M. Nicolas, M. Gay, A. Walpersdorf, J.-L. Mugnier, J. Serafini, D. Rosu, L. Bombrun, G. Vasile, N. Cotte, F. Vernier, F. Tupin, L. Moreau, and P. Bolon, "Monitoring Temperate Glacier Displacement by Multi-Temporal TerraSAR-X Images and Continuous GPS Measurements," IEEE Journal of Selected Topics in Applied Earth Observations and Remote Sensing, vol. 4, no. 2, pp. 372-386, Jun. 2011.

[20] E. Berthier and C. Vincent, "Relative contribution of surface mass-balance and ice-flux changes to the accelerated thinning of Mer de Glace, French Alps, over 1979-2008," Journal of Glaciology, vol. 58, no. 209, pp. 501-512, Jun. 2012.

[21] C. Vincent, M. Harter, A. Gilbert, E. Berthier, and D. Six, "Future fluctuations of Mer de Glace, French Alps, assessed using a parameterized model calibrated with past thickness changes," Annals of Glaciology, 2014.

[22] E. Berthier, C. Vincent, E. Magnússon, A. P. Gunnlaugsson, P. Pitte, E. Le Meur, M. Masiokas, L. Ruiz, F. Pálsson, J. M. C. Belart, and P. Wagnon, "Glacier topography and elevation changes derived from Pléiades sub-meter stereo images," The Cryosphere, vol. 8, no. 6, pp. 2275-2291, Dec. 2014. [Online]. Available: http: //www.the-cryosphere.net/8/2275/2014/

[23] T. G. Farr, P. A. Rosen, E. Caro, R. Crippen, R. Duren, S. Hensley, M. Kobrick, M. Paller, E. Rodriguez, L. Roth, and others, "The shuttle radar topography mission," Reviews of geophysics, vol. 45, no. 2, 2007. [Online]. Available: http://onlinelibrary.wiley.com/ doi/10.1029/2005RG000183/full
[24] D. Six and C. Vincent, "Sensitivity of mass balance and equilibrium-line altitude to climate change in the French Alps," Journal of Glaciology, vol. 60, no. 223, 2014.

[25] H. Rott and T. Nagler, "Monitoring temporal dynamics of snowmelt with ERS-1 SAR," in Geoscience and Remote Sensing Symposium, 1995. IGARSS'95.'Quantitative Remote Sensing for Science and Applications', International, vol. 3. IEEE, 1995, pp. 1747-1749. [Online]. Available: http://ieeexplore.ieee.org/xpls/abs_all. jsp?arnumber $=524014$

[26] S. Leinss, A. Wiesmann, J. Lemmetyinen, and I. Hajnsek, "Snow Water Equivalent of Dry Snow Measured by Differential Interferometry," IEEE Journal of Selected Topics in Applied Earth Observations and Remote Sensing, vol. 8, no. 8, pp. 3773-3790, Aug. 2015. [Online]. Available: http://ieeexplore.ieee.org/lpdocs/epic03/ wrapper.htm?arnumber $=7128327$

[27] E. Brun, P. David, M. Sudul, and G. Brunot, "A numerical model to simulate snow-cover stratigraphy for operational avalanche forecasting," Journal of Glaciology, vol. 38, pp. 13-22, 1992. [Online]. Available: http://adsabs.harvard.edu/abs/ 1992JGlac..38...13B,

[28] V. Vionnet, E. Brun, S. Morin, A. Boone, S. Faroux, P. Le Moigne, E. Martin, and J. M. Willemet, "The detailed snowpack scheme Crocus and its implementation in SURFEX v7. 2," Geoscientific Model Development, vol. 5, pp. 773-791, 2012. [Online]. Available: https: //hal-insu.archives-ouvertes.fr/insu-00844645/

[29] J. Noilhan and J. F. Mahfouf, "The ISBA land surface parameterisation scheme," Global and Planetary Change, vol. 13, no. 1-4, pp. 145-159, Jun. 1996. [Online]. Available: http://www.sciencedirect.com/science/ article/pii/0921818195000437 
[30] Y. Durand, M. Laternser, G. Giraud, P. Etchevers, B. Lesaffre, and L. Mérindol, "Reanalysis of 44 Yr of Climate in the French Alps (1958-2002): Methodology, Model Validation, Climatology, and Trends for Air Temperature and Precipitation," Journal of Applied Meteorology and Climatology, vol. 48, no. 3, pp. 429-449, Mar. 2009. [Online]. Available: http://journals.ametsoc.org/ doi/abs/10.1175/2008JAMC1808.1

[31] Y. Durand, G. Giraud, E. Brun, L. Mérindol, and E. Martin, "A computer-based system simulating snowpack structures as a tool for regional avalanche forecasting," Journal of Glaciology, vol. 45, no. 151, pp. 469-484, 1999. [Online]. Available: http: //cat.inist.fr/?aModele $=$ afficheN\&cpsidt $=1253314$

[32] M. Lafaysse, S. Morin, C. Coléou, M. Vernay, D. Serça, F. Besson, J.-M. Willemet, G. Giraud, Y. Durand, and D. MétéoFrance, "Towards a new chain of models for avalanche hazard forecasting in French mountain ranges, including low altitude mountains," in Proceedings of International Snow Science Workshop Grenoble-Chamonix Mont-Blanc, 2013. [Online]. Available: http://arc.lib.montana.edu/ snow-science/objects/ISSW13_paper_O1-02.pdf

[33] C. Werner, U. Wegmüller, T. Strozzi, and A. Wiesmann, "Gamma SAR and interferometric processing software," in ERSENVISAT Symposium, Gothenburg, Sweden. Citeseer, 2000, pp. 16-20. [Online]. Available: http://citeseerx.ist.psu.edu/viewdoc/download? doi=10.1.1.20.6363\&rep=rep1\&type $=$ pdf

[34] T. Strozzi, A. Luckman, T. Murray, U. Wegmuller, and C. L. Werner, "Glacier motion estimation using SAR offset-tracking procedures," Geoscience and Remote Sensing, IEEE Transactions on, vol. 40, no. 11, pp. 23842391, 2002. [Online]. Available: http://ieeexplore. ieee.org/xpls/abs_all.jsp?arnumber $=1166597$

[35] R. M. Goldstein and C. L. Werner, "Radar interferogram filtering for geophysical applications," Geophysical Research Letters, vol. 25, no. 21, pp. 4035-4038, 1998. [Online]. Available: http://onlinelibrary.wiley.com/ doi/10.1029/1998GL900033/full

[36] M. Costantini, "A novel phase unwrapping method based on network programming," IEEE Transactions on Geoscience and Remote Sensing, vol. 36, no. 3, pp. 813-821, May 1998.

[37] R. Myneni and F. Hall, "The interpretation of spectral vegetation indexes," IEEE Transactions on Geoscience and Remote Sensing, vol. 33, no. 2, pp. 481-486, Mar. 1995.

[38] C. Nuth and A. Kääb, “Co-registration and bias corrections of satellite elevation data sets for quantifying glacier thickness change," The Cryosphere, vol. 5, no. 1, pp. 271-290, Mar. 2011. [Online]. Available: http://www.the-cryosphere. net/5/271/2011/

[39] J. Höhle and M. Höhle, "Accuracy assessment of digital elevation models by means of robust statistical methods," ISPRS Journal of Photogrammetry and Remote Sensing, vol. 64, no. 4, pp. 398-406, Jul. 2009. [Online]. Available: http://linkinghub.elsevier.com/retrieve/ pii/S0924271609000276

[40] M. Gerbaux, C. Genthon, P. Etchevers, C. Vincent, and J. Dedieu, "Surface mass balance of glaciers in the French Alps: distributed modeling and sensitivity to climate change," Journal of Glaciology, vol. 51, no. 175, pp. 561-572, Dec. 2005.

[41] A. Rabatel, A. Letréguilly, J.-P. Dedieu, and N. Eckert, "Changes in glacier equilibriumline altitude in the western Alps from 1984 to 2010: evaluation by remote sensing and modeling of the morpho-topographic and climate controls," The Cryosphere, vol. 7, no. 5, pp. 
1455-1471, Sep. 2013. [Online]. Available: http:

//www.the-cryosphere.net/7/1455/2013/

[42] C. Vincent, E. Le Meur, D. Six, M. Funk, M. Hoelzle, and S. Preunkert, "Very highelevation Mont Blanc glaciated areas not affected by the 20th century climate change," Journal of Geophysical Research, vol. 112, no. D9, May 2007. [Online]. Available: http://doi.wiley.com/10. 1029/2006JD007407

[43] M. Huss, "Density assumptions for converting geodetic glacier volume change to mass change," The Cryosphere, vol. 7, no. 3, pp. 877887, May 2013. [Online]. Available: http://www. the-cryosphere.net/7/877/2013/

[44] M. Fischer, M. Huss, and M. Hoelzle, "Surface elevation and mass changes of all Swiss glaciers 1980-2010," The Cryosphere, vol. 9, no. 2, pp. 525-540, Mar. 2015. [Online]. Available: http://www.the-cryosphere.net/9/525/2015/

[45] R. Bamler and M. Eineder, "Accuracy of differential shift estimation by correlation and splitbandwidth interferometry for wideband and deltak SAR systems," IEEE Geoscience and Remote Sensing Letters, vol. 2, no. 2, pp. 151-155, Apr. 2005.

[46] R. Brcic, M. Eineder, and R. Bamler, "Absolute phase estimation from TerraSAR-X acquisitions using wideband interferometry," in Proceedings of IEEE Radar Conference, 2008. [Online]. Available: http://sss.terrasar-X.dlr.de/papers_sci_ meet_3/poster/MTH0366_brcic.pdf

[47] D. De Rauw, F. Kervyn, N. d'Oreye, B. Smets, F. Albino, and C. Barbier, "Split-Band Interferometric SAR Processing Using TanDEM-X Data," in FRINGE 2015, 2015. [Online]. Available: http://orbi.ulg.ac.be/handle/2268/179826 